\title{
Heritage Spectacles: The Case of Amphipolis Excavations during the Greek Economic Crisis
}

\section{Introduction}

Late 2009 marked the onset of the most severe economic crisis in post-war Europe. Greece was one of the hardest hit economies of all peripheral Eurozone members, whereas the handling of its sovereign debt crisis in subsequent years forced on-going economic recession and socio-political unrest (Markantonatou 2013; Matsagkanis 2013). Soon, the narratives of the crisis contributed to negotiations of national identity, where heritage and the past served as catalysts for self-questioning, protest and the remaking of notions of Greekness.

Witnessing the impact of the economic crisis on the identity of 'Modern Greeks', the Principal Investigator of the Economic Crisis, Heritage and Identity in Europe (ECHIE) project $^{1}$ instigated a study in 2013 aimed at exploring the use of heritage in deconstructing and reconstructing 'fragile' national identities in the context of economic crises. The focus of the study was around the ways in which heritage was used in media discourses (mostly newspapers) as a means to negotiate national identities since the emergence of the Greek crisis. More than 400 newspaper articles published in the most widely circulated Greek newspapers of different political angles since $2009^{2}$ were singled out and analysed through content analysis on the NVivo software. The content analysis was initially carried out independently and then jointly

\footnotetext{
${ }^{1}$ http://www.ucl.ac.uk/european-institute/events/2013-14/greece

2 Ta Nea (centre-left); Ethnos (centre-left); To Vima (centre-ledt); Kathimerini (centre-right); Avgi (leftwing); Proto Thema (weekly, right-wing, populist); Xrisi Avgi (newspaper of Golden Dawn); Imerisia: Daily Financial Newspaper
} 
by the two authors in order to minimize subjectivity. This analysis shed light on a wide spectrum of heritage-featuring narratives, employed by various political and social forces.

Interestingly, out of the 400 newspapers articles, 110 related exclusively to the Amphipolis excavations with most of them deriving from the righ-wing newspaper Kathimerini ${ }^{3}$. Indeed, the media portrayal of the excavations that were taking place in Amphipolis, Northern Greece, during summer 2014 took an unprecedented form $\left(\right.$ Vournelis 2016) ${ }^{4}$. This is further reflected in social media and blogs at the time which is subject of further research. The Amphipolis excavations were part of the wider cultural policy of the then coalition government led by the right-wing party, Nea Democratia, to promote heritage projects of international significance despite the economic austerity. These included, for instance, the re-ignition of the claim for the repatriation of the Parthenon Marbles and the underwater excavations on the island of Antikythera where the famous 'mechanism' of Antikythera was found (e.g. Williams, Pizarro and Foley 2016).

It is worth noting at this point that Amphipolis is imbued with high 'symbolic capital' (Hamilakis and Yalouri 1996) as this is the place where the wife and son of Alexander the Great were likely buried. Undoubtedly, Alexander the Great is one of the most iconic symbols in Greece, as was further verified in the Greek Show entitled Great Greeks ${ }^{5}$ during which Alexander the Great was voted by a significant majority of the Greek public as the 'Greatest Greek'. The iconic significance of Alexander the Great

\footnotetext{
${ }^{3}$ Ethnos: 28; To Vima: 19; Kathimerini: 52; Proto thema: 3; Avgi: 8; Imerisia: 1

${ }^{4}$ For the history of the Amphipolis excavations please see also Archibald et al. 2014

${ }^{5}$ Great Greeks is a television show based on the BBC's equivalent television programme 100 Greatest Britons.
} 
explains the persistence of archaeologists over the years to discover his tomb. This is further reaffirmed by he intensive media portrayal of the discovery of the tomb of King Philip II, father of Alexander the Great, in 1977, at Vergina, Northern Greece (Kotsakis 1988). The discovery of the unlooted grave of King Philip II constituted the "most spectacular archaeological find of the last decades' and was presented in November 1977 to a 'thrilled audience' within a 'packed auditorium' at the University of Thessaloniki (Kotsakis 1998, 44). The archaeological discovery in Vergina not only was transformed into a media spectacle at the time but also became a powerful political tool for the ongoing Macedonia naming dispute since the 1980s -an unresolved and nationalistically charged issue between Greece and the Former Yugoslav Republic of Macedonia (FYROM) over the name of the latter and by extension, over the ethnic/historic identity of the region (Mavromatidis 2010).

Our content analysis adopted a grounded theory analytical approach allowing the thematic analysis of the newspaper data to drive the theory (Corbin and Strauss 1990). Our content analysis identified eight main themes including: the portrayal of Amphipolis as a reality show - an everyday show of agony and thrill; the political use of Amphipolis for distracting the public from dystopia (politics of distraction); an orchestrated political attempt to further feed the myth of Alexander the Great; the use of Amphipolis for fostering national pride and a sense of national euphoria; an emphasis on the uniqueness of the discovery and the sacredness of the objects; and finally, the use of Amphipolis as an inspiration to discuss everyday social and political issues. The thematic analysis clearly showed that the Amphipolis excavations were used by politicians as a spectacle intended to distract Greeks' attention from the socio- 
economic crisis. It is the aim of this paper to unfold the mechanisms by which the Amphipolis spectacle was constructed in the context of the economic crisis.

The media frenzy of Amphipolis started once a group of state archaeologists reached the entrance of a tomb, surrounded by a 497-metre tumulus at Kasta Hill and guarded by two marble sphinxes that framed its entry arch. Shortly afterwards, their images were widely circulated in the media and featured on newspaper covers. Daily newsfeeds on the archaeological excavations changed archaeological research into a quasi 'drama series' cultivating a fertile ground for political manoeuvring and distraction from depressing economic developments as well as providing an arena for expert quarrels. Consequently, Amphipolis was converted into a source of hope and escape from the economic national dystopia. The role of Amphipolis excavations in devising a sense of national euphoria was expedited by a phenomenal process of 'spectacularisation' which renders Amphipolis a unique example for unfolding the mechanics of 'heritage spectacle' production. By disentagling the mechanics of the spectacularisation of Amphipolis the political dimensions of heritage will be unravelled.

Our starting theoretical point of departure is the work of the Marxist philosopher Guy Debord, The Society of the Spectacle (1967). This piece is a manifesto of 221 theses against consumerist culture and, despite its criticisms and weaknesses, it has been one of the most influential works for a diverse range of studies including anthropological, cultural, sociological and geographical studies in media, sports, theatre and performance. Three of the dimensions of spectacle highlighted in Debord and further elaborated by Kaplan (2012) seem to be of particular relevance for the case of Amphipolis. The three dimensions include (i) the creation of 'banal fantasies', (ii) the 
representation of society as a unified and meaningful whole, and (iii) the outlining of inequalities in the power to name and define the spectacle. Conclusively, the article proposes a conceptual framework for 'heritage spectacles' that could be utilized as an analytical tool for understanding and deconstructing the mechanics of the spectacularisation of heritage. In sum, the article is divided into four main sections. The first section endeavours to conceptualise heritage spectacles. The second section discusses the spectacularisation of Amphipolis and presents the key findings of our content analysis as they fit into these dimensions. The third section links the theorisation of spectacle with the findings and proposes a framework for deconstructing the mechanics of heritage spectacles. Finally, our concluding section highlights critical implications for archaeologists and heritage professionals regarding their stance towards the political uses of heritage in periods of crisis.

\section{Conceptualising 'heritage spectacles'}

The term 'spectacle' generally signifies a dazzling staged show that is perceived to be watched and consumed passively by certain audiences (Kaplan 2012, 471). In critical theory, the 'spectacle' provides an allegorical schema that describes and critiques the use of mass media productions for transforming citizens into politically neutralised subjects (Adorno and Horkheimer 1997; Debord 1967). By overwhelming viewers with ideas and behaviours, the spectacle acts as an ideological mechanism that introduces and reproduces specific ways of seeing the world while displaying a deceptive unity across a divided society (Kellner 2003; Mylonas 2012). 
As with other forms of spectacle, we argue that the 'heritage spectacle' exposes itself through the mass generation and circulation of media content, such as newspaper articles, reports and audio-visual material (Kellner 2003). Similarly to other forms of 'staged' heritage, the spectacle is characterised by theatricality, the power to form shared identities and the capacity to pacify its recipients (Kong and Yeoh 1997; Tomlinson and Young 2006).

Although existing literature in heritage does not provide a relevant theory on 'heritage spectacle', previous research illustrates that the 'spectacularisation' of heritage is not a new conception, but rather one that can be traced as far back as to the nineteenth century. An indicative example is the German archaeologist, Heinrich Schliemann, who 'staged his life as a spectacle' promoting himself as an archaeological hero and adventurer through the popular means of his time including travel guides, photography and moving panoramas (Maurer 2009, 303). In Britain, we find analogous spectacularisations featuring Egyptian artefacts and theatrical spectacles invoking British nationalist pride by using Ancient Egypt as both subject and setting (Thomas 2012).

Contemporary forms of heritage spectacles can be seen in major cultural events such as the Modern Olympic Games (MacAloon 2006). The opening and closing ceremonies of the 2004 Olympic Games in Athens, for instance, formed a staged spectacle that aimed to commemorate the past while revalidating national discourses of continuity and inheritance in the present (Plantzos 2012). Nevertheless, it is not only the celebration of heritage that is being spectacularised, but also its destruction. Harmanşah has discussed how the Islamic State 'choreographs' the destructions of cultural heritage 
'as mediatic spectacles of violence aimed at objects and sites of heritage' $(2015,170)$. He further contends that these spectacles function as 're-enactments' or 'historical performances' that are constantly communicated through 'ISIS's own image-making and dissemination apparatus that increasingly utilizes the most advanced technologies of visualization and communication' $(2015,170)$.

The examples above indicate that the spectacularisation of heritage is not a new phenomenon. However, although heritage has been spectacularised in various ways and has often been used to nourish national imagination and construct personal and collective identities (Damaskos and Plantzos 2008; Hamilakis 2007; Yalouri 2001), we maintain that in the mid-crisis Greek context, the spectacularisation practice of antiquity and archaeological research took a novel and unprecedented form. Indeed, the media portrayal of Amphipolis' excavations resembled the mechanics of a soap opera.

Our theoretical point of departure to conceptualise heritage spectacle and the mechanisms of its production is informed by the influential study of Guy Debord entitled 'Society of the Spectacle' (1967). In his work, the famous Marxist philosopher, analyses the French consumerist society of his time, a society that is dominated by the production and consumption of images and staged events leading to social alienation. The critique of Debord has been extensively used in numerous consequent publications since then, covering a vast array of disciplines and subject areas. In the early 1970s, the Society of Spectacle was first used to interpret political movements of the time, especially in France (e.g. Apter and Joll 1971; Gombin 1970). Soon Debord's manifesto became a popular framework tool for political and cultural studies beyond the French borders. Towards the end of the 1970s the Society of Spectacle was used in theatre and 
performance studies with particular emphasis on the role of theatrical space as a medium of connectivity with audiences (e.g. Ross 1977). In the early 1980s, the Society of Spectacle inspired research in political economy and tourism studies aimed at showing how sites and cultural symbols were being branded and spectacularized (e.g. Overton 1980). From the mid 1980s, cultural studies with a focus on media and consumption (e.g. Kellner 1983) were increasingly drawing on Debord while in the late 1980s and early 1990s geographers started re-examinaning landscapes and urban scapes as a form of spectacle, a staged event where social and spatial interactions are at interplay (e.g. Peponis 1989; Shields 1989; Harvey 1990; Kong and Yeoh 1997). The geographers were soon followed by anthropologists with an interest in studying theatre and spectacles as distinct cultural institutes and with emphasis on the creation of cultural meaning within the framework of theatre and spectacle (e.g. Beeman 1993). In early $21^{\text {st }}$ century studies, the spectacularization of sports (e.g. Tomlinson 2002; Tomlinson and Young 2006; Creak 2010; Kang and Traganou 2011; Jackson and Sherer 2013; Andrews 2005), the role of media in the spectacularization process of political or other events (e.g. Kellner 2010; Rosati 2012; Bachmann 2016) and the theorization of performance and theatre utilize the Society of Spectacle as a starting theoretical point (Kershaw 2001; 2003; Parry 2010). It is worth noting that although Debord has constituted the point of departure in spectacle studies, his principles have largely been critiqued. Berman et al (1990) have for instance interrogated the diachronic validity of Debord's critique of the consumer society of the time given that the capitalism under critique was already obsolete by the mid 1960s. Roberts (2003) criticised Debord's lack of differentiation between the various types of spectacle which reflect different types of economies and political states. As a result Debord's analysis becomes 'too compact to be analytically useful' (Roberts 2003, 58). Kaplan 
characterises Debord's analysis as a 'one-dimensional understanding of the contending forces of our era' overestimating the 'degree in which individual subjects are integrated into this alienated cultural construction' $(2012,458)$. However, despite these critiques, there are certain elements mentioned in the Society of Spectacle that seem to be of diachronic relevance to our 'contemporary spectacular world' (Kaplan 2012, 463) and, certainly, to the case of Amphipolis. The three key dimensions that are of pertinence to the case of Amphipolis include:

(i) the creation of 'banal fantasies', (ii) the representation of society as a unified and meaningful whole, and (iii) the outlining inequalities in the power to name and define the spectacle. (Kaplan 2012, 464).

The first dimension relates to the promotion of 'banal fantasies'. By this term, Debord refers to the banalisation and fantastic portrayal of enlarged celebrity personalities implicit in media spectacles (Kaplan 2012, 464). For Debord, in the alienated societies of late capitalism, a change in the very form and content of cultural representation necessarily accompanies the loss of individual voice, group interaction and participatory accomplishment. Thus, the banal and fantastic portrayal of celebrity personalities (also named as 'media stars' or 'pseudostars' by Debord (1967, Thesis 60)) acts as a 'compensation for the individual's lost freedom and purpose in everyday life' (Kaplan 2012, 464). One of the main issues here is that Debord implies that the spectacle, offering banal fantasies through mainly the fantastic portrayal of celebrities, is founded on the extreme isolation and passivity of the audience. However, the assumption that the audience passively accepts the banal fantasies should definitely be queried (see also: Gotham 2007; Kaplan 2012, 464).In the context of heritage, 'banal fantasies' often acquire a national tone to fulfil political ends echoing what Billig calls 
processes of 'banal nationalism' (1995). Billig uses this term to refer to the everyday production and use of banal and clichéd symbols (such as flags hanging on public buildings or in the street) in the so-called 'Western' nations which function as constant reminders of nationhood (Billig 1995, 6). The underlying nationalism becomes more prominent at periods of crises - such as in the case of Greece during which emergence of nationalism among extreme-right wing parties and intensive nationalist rhetoric on media and press can often be observed. However, as Billig contends (1995, 6), it is not that the crises create (or re-create in our case) a nation-state, 'it is that nations are reproduced within a wider world of nations' (Billig 1995, 6). The everyday reproduction of the nation-state relies on the banal and mundane reproduction of a 'whole complex of beliefs, assumptions, habits, representations and practices' (Billig $1995,6)$. In other words, there is a constant 'flagging' or 'reminding' of nationhood (Billig 1995, 8) which, as we further argue, becomes more intense and discernible in periods of political, social and economic crises. The earnestness of this 'reminding' in periods of crises can be explained by the fact that 'nationhood provides a continued background for their political discourses, for cultural products and even for the structuring of newspapers' (Billig 1995, 8). Billig stresses that the reminding is so familiar and continual that is not consciously registered as reminding (Billig 1995, 8). In the case of crises, as in the case of Greece, the constant use of iconic cultural symbols in the everyday press signifies the profound effort of politicians to remind Greeks of 'what makes them Greeks' so that the fragile national identity is re-stabilised.

More importantly, the reproduction of nation-states and national identities by political powers in particular depends upon the dialectic between collective remembering and forgetting, imagination and unimaginative repetition (Billig 1995, 10). As we will see 
in the case of Amphipolis, these processes happen in parallel and one feeds the other. Those holding the political and media power attempt to achieve collective remembering of a glorious past through the spectacularisation of Amphipolis alongside the collective forgetting of the crisis and its dramatic socio-political consequences. The role of politicians in the reproduction of collective remembering through the repetitive use of discourses and banal symbols is instrumental. Politicians, as Billig argues and as we observe in Amphipolis, mutate into key spectacle agents whose words typically reproduce the clichés of nationhood while continually reporting in the mass media (Billig 1995, 11). It is worth stating here that such mechanisms of collective remembering and collective forgetting are not necessarily 'successful'. As Vournelis has shown $(2016,124)$, segments of the Greek public are resisting or critically reflecting towards the 'Amphipolis spectacle' which they clearly see as a political attempt of disorientation of the public from the real problems. Others, on the other hand, as shown in our personal, informal communications have stressed that the 'Amphipolis spectacle' has provided a means of escape from the harsh contemporary issues. Reactions of the Greek public are most certainly mixed. A thorough investigation of the public reception of the 'Amphipolis excavations' would be an interesting, follow-up piece of research.

The second dimension of spectacle refers to the production of societal representations that reflect a unified, meaningful whole (Kaplan 2012, 463). This is accomplished through the provision of legitimised ideas and ideals that 'obfuscate reality' (Gotham 2007, 85) and the employment of mass media spectacles that intend to distract societies from critical issues (Debord 1967; Harp, Loke and Bachmann 2016; Kellner 2003; Schirato and Webb 2004). The 'meaningful whole' (Kaplan 2012, 463) is further 
reinforced by spectacles that publicly display elements meaningful to the spectator (Beeman 1993) often encompassing contemporary, societal basic values and norms (Harp, Loke and Bachmann 2016). Similarly to the dimension of banal fantasies, this dimension fails to accept the permanent, decentered and dialogical dimensions of social representation' (Kaplan 2012, 466) and implies that a select group 'creates a distinct cultural perspective of the social whole, cut off from and denying its roots in social production' (ibid). However, it still represents how the power holders attempt to represent societies as a meaningful whole in order to achieve their political goals. Especially, in the context of crisis in Greece during which national identities are fragile, we observe how political powers use the spectacle of Amphipolis as a tool to re-unite and re-establish fragmented national identities. In crisis dystopia, the spectacle can be transformed into a visual soap opera projecting 'images of happiness' (Gotham 2007) while harvesting cultural nationalism (Brown 1996). As a result the production and provision of heritage spectacles leads to a process of nations' 're-imagination' (Creak 2010; Jackson and Sherer 2013, 885).

The third dimension of spectacle invokes the inequalities in the production and control of cultural meaning (Kaplan 2012, 465; see also Edelman 1988). Such inequalities occur through the concentration of the means of communication power in the hands of minorities (Kaplan 2012, 465). This idea reinforces Smith's (2006) analysis of 'authorized heritage discourses' that prevail current heritage management practices. Authorized heritage discourses acknowledge the legitimate guardianship of heritage by experts and as such privilege their values of heritage (Smith 2006). This third dimension again fails to capture the dynamic exchange of social interactions in public communications, implying a massive, passive society (Kaplan 2012, 466). In other 
words, Debord 'elaborates a model of absolute separation and displacement' with 'all means of speech concentrated in the "hands of experts who now pretend to speak for the whole' (Kaplan 2012, 466). Resistance or public opposition is not captured in Debord's manifesto. Despite those weaknesses, since the focus of this paper is to uncover the mechanisms of spectacularization by the power holders and not the public reception of the mechanisms the three dimensions analysed above can provide a useful tool of analysis for the Amphipolis case. In other words, Debord's analysis - and especially the three aspects outlined above - will enable us to understand how the agents of the Amphipolis spectacle production assume a passive Greek public and attempt to develop a top-down, hegemonic heritage narrative that aims to distract the Greek society from the real socio-economic issues of the time.

The three dimensions of spectacle, banal fantasies, representation of a unified society and inequalities in the production of cultural meaning, are clearly evident in the case of Amphipolis. As the following sections illustrate, a vast part of the spectacularisation of Amphipolis gained theatricality through cliché schemata, emotionalised language and the heroization of spectacle 'protagonists'. Through associations with antiquity (e.g. Alexander the Great as reminiscence of a glorious past) and the positioning of heritage as a means to change the future (e.g. to improve economic climate), the heritage spectacle sought the power to foster pride and national uplift. Ultimately, the spectacle was intended by certain media discourses to pacify a divided society and camouflage its dysphoria. Additionally, political leaders were legitimised to publicise and interpret the archaeological finds while other archaeologists join the 'game of a fame' by offering their own archaeological interpretation in the media. The following section 
illustrates in detail how the heritage spectacle of Amphipolis developed in the Greek press.

\section{The Amphipolis spectacle}

\section{Banal fantasies}

The first dimension of the spectacle, banal fantasies, manifested itself through the use of emotive language for popularising romanticized notions of archaeology and banal symbols of cultural identity. Spectacle narrations were also used to propagate illusionary prospects and fantasies pertinent either to beliefs of tourism-led growth that promised the alleviation of economic hardships, or to expectations of retrieving hard evidence in favour of Greece's territorial claims and ethnic integrity.

Starting with emotive language, we observe the use of affective vocabulary mobilised to bolster romanticized views of archaeology associated with emotions of discovery and excitement (Colley 2005). Amphipolis was described in the media as an archaeological 'riddle' from the past (To Vima, August 17, 2014), a 'miracle' (Ethnos, August 25, 2014) and a 'mystery' (Kathimerini, September 14, 2014) waiting 2,500 years for its revelation (To Vima, August 12, 2014; Ethnos, August 15, 2014). In turn, the excavations were characterised as 'a beautiful adventure' (To Vima, September 8, 2014) and a project featuring surprises and 'the element of the unexpected' (Proto Thema, September 12, 2014; To Vima, September 17, 2014). 
The representation of the archaeological excavations as an exciting adventure reinforced idealistic and often clichéd perceptions of archaeology, capturing effectively viewers' imaginations (e.g. the Indiana Jones popular culture persona). The romantic view towards archaeology was further linked with a sense of timelessness that archaeology can inspire and a feeling that the past, through its ruins, may become tangible itself, as hinted in the following newspaper excerpts [1] and [2]: .

'For the first time in my life I am so close to such a great [archaeological] mystery!' PM's statement, To Vima, August 12, 2014 [1]

'Every step on Amphipolis feels like a step back in [historic] memory ${ }^{7}$ ' (emphasis added)

To Vima, September 28, 2014 [2]

As mentioned above, Amphipolis is directly linked to Alexander the Great who holds a prominent position in Greek national identity and imagination (Hamilakis 2015). This is further reaffirmed by the results of our broader content analysis within the framework of [Project Title will be inserted here after the completion of the review process], which revealed the noticeable preference of Alexander the Great as the key cultural symbol, especially of extreme-right newspaper discourses. The linkage of Amphipolis to Alexander the Great not only made the discovery of Amphipolis inherently attractive to Greek audiences but also drove archaeologists and political leaders to date (rather speculatively) the find to the Macedonian era and to making direct references to its 'Macedonian land' (To Vima, September 12, 2014). As excerpts [3] and [4] sketch out,

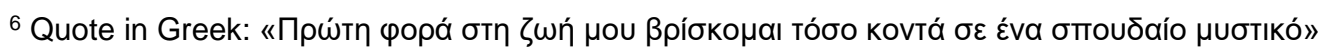

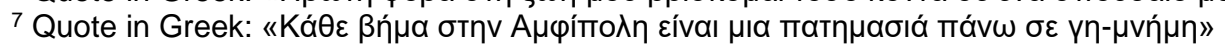


the banal fantasy of bringing to light more information about Alexander added a sense of thrill to the excavation process.

'Thousands of people follow excavation announcements with thrill, anticipating that it would be $\operatorname{Him} . .{ }^{8}$, (emphasis added)

To Vima, September 29, 2014 [3]

'Just the idea that it might be Alexander makes us feel awe 9 ' (emphasis added)

Testimony by an Amphipolis' visitor in Kathimerini, September 29, 2014 [4]

Along with Alexander, the two female figures (Caryatids) unearthed during the excavations became a new important cultural symbol. The drawing of parallels with Acropolis' statues in Athens and the finds' characterisation as 'sacred' (To Vima, September 9, 2014) led to their preferment as affective images of cultural identity [5].

'Archaeologists and the public [are] moved by the Caryatids of Ancient Amphipolis. The way towards the discovery of the burial monument is full of surprises $^{10}$,

To Vima, September 9, 2014 [5]

Furthermore, in some newspaper representations, on-site archaeologists were elevated into a new form of 'pseudo-stars', illusionary celebrities and heroes, to echo Debord.

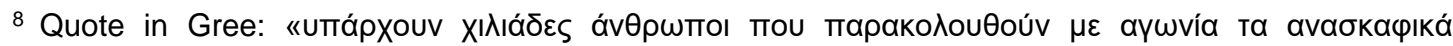

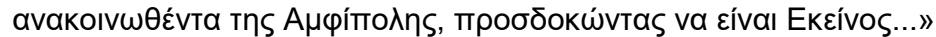

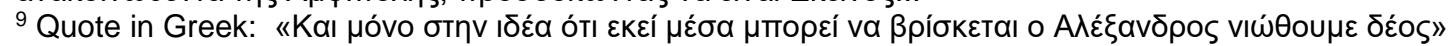

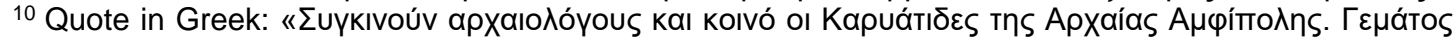

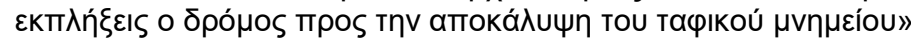


The archaeologists were praised in the press for their courage to accomplish the ambitious project and reveal the truth (Kathimerini, August 24, 2014; Proto Thema, September 9, 2014; Ethnos, September 14, 2014), as evidenced by excerpts [7] and [8]:

'Night and day, [the archaeologists] are digging their fingernails into the ground $^{11}$ '

Ethnos, 20 Sep 2014 [7]

'During the past month, even in the evening, [the Director's assistant] goes around wearing a wide-brimmed hat to avoid the cameras ${ }^{12}$.'

Ethnos, September 14, 2014 [8]

Special attention was paid to the director of the excavations, who was admired by local people (To Vima, September 28, 2014) and the press for her 'personal persistence' (Ethnos, August 15, 2014) and 'struggle' (To Vima, August 27, 2014), both catalysts of the find's unearthing [9].

'The low profile archaeologist continued her efforts with patience [and] got in the spotlight a year before her retirement ${ }^{13}$.'

Ethnos, August 25, 2014 [9]

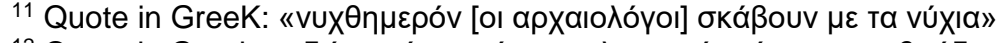

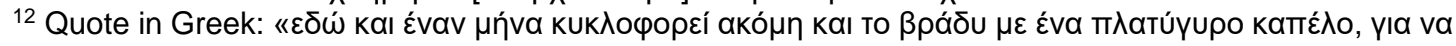

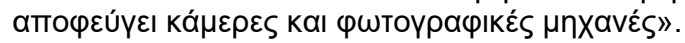

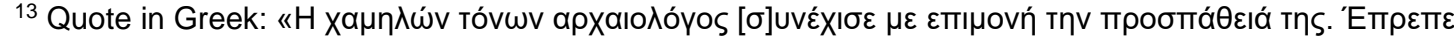

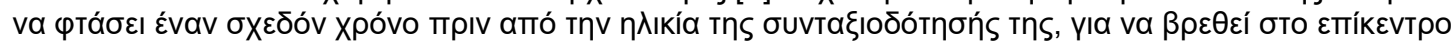

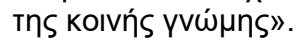


In terms of encouraging illusionary prospects and banal fantasies, the adumbration of the Tomb was presented as holding the potential to help the country exit the crisis through tourism and wider economic development (Kathimerini, August 24, 2014; 2014; Ethnos, August 25, 2014; To Vima, September 19, 2014; Proto Thema, September 29, 2014). Narratives intended for internal consumption also highlighted the economic extension of the discovery, implying that a small and ruined country could still survive by exporting its remarkable heritage capital and balancing its financial shortcomings.

As it was highlighted, tourists were lured to visit the site in order to witness the impressive discovery (To Vima, September 28, 2014), leading in turn to skyrocketing land prices in the area (Proto Thema, September 21, 2014). The find's global appeal and economic potential was repeatedly stressed not only by journalists [10-11] but also by state leadership [12].

'Amphipolis will constitute an international attraction for visitors and a strong asset for the economic development of the area ${ }^{14}$.'

Imerisia, 30 Aug 2014 [10]

'A Chinese tourist who lives in Texas, US, was starring at the Tomb openmouthed. [He] had heard about it in National Geographic and wanted to witness the discovery ${ }^{15}$,

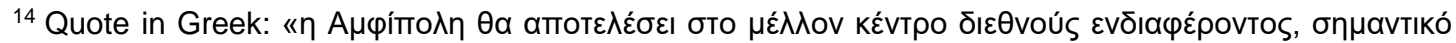

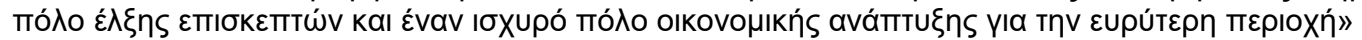

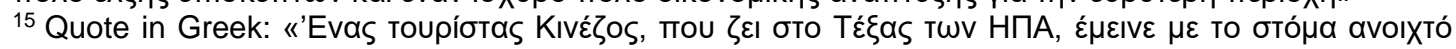

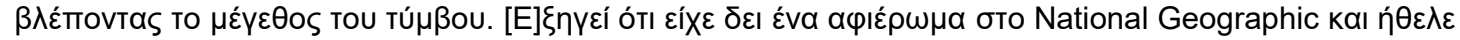

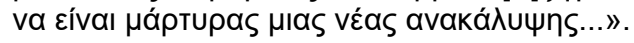


'Amphipolis will form a new destination of attraction, similar to this of Vergina, and a new competitive advantage for Serres region ${ }^{16}$.

Statement by Deputy PM, Kathimerini, September 7, 2014 [12]

Apart from economic speculation of exiting the crisis, and perhaps more interestingly, banal fantasies were also linked to territorial issues. As mentioned above, Amphipolis was associated with the Macedonia naming dispute. Similarly to Andronikos' excavation of a royal tomb in Vergina in the 1970s, which was described as the tomb of Alexander's father, the potential unearthing of a historic figure of the same period was anticipated as an 'un-falsifiable testament' that Greece is the legitimate owner of the name 'Macedonia' (Hamilakis 2007, 130). Thereupon, the spectacle fertilised the notion that Amphipolis' material evidence would compensate for the failure of diplomatic talks (To Vima, August 15, 2014; Ethnos, September 21, 2014; Kathimerini, September 7, 2014; Proto Thema, September 16, 2014) or even turn its tide of history [13].

'[Amphipolis] would re-write history books and heavily influence the fate of Greece $^{17}$,

Proto Thema, September 9, 2014 [13]

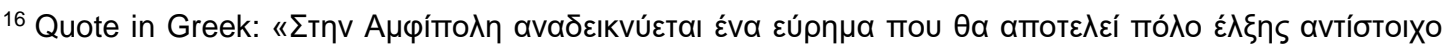

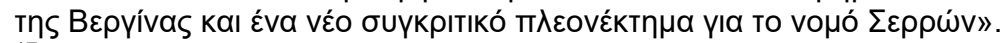

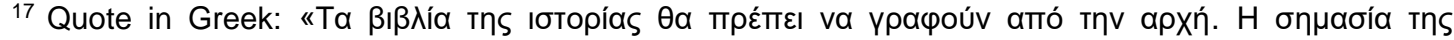

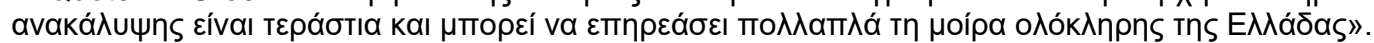


The banal fantasies of illusionary prospects confirm the observation of Plantzos (2014) that Amphipolis' media narratives, although concerned with an archaeological find which could inherently reveal information about the past, placed most of their interest on how it could influence the present and the future. The banal symbols and aspects of the Amphipolis spectacle, i.e. romanticism, symbolism, pseudo-heroes and the employment of archaeology for the resolution of economic and political problems as deus ex machina, represent some of the key components of a heritage spectacle.

The following section proceeds with the second dimension of spectacle -i.e. the representation of society as a meaningful whole.

\section{Escapism and re-unification of society}

The second dimension refers to the spectacle's role in representing societies as a meaningful whole by offering a means of escape from the dystopia of the crisis. At the time of the Amphipolis excavations, the Greek society was largely divided. Three months prior to the excavations, in May 2014, elections for the European parliament and the Greek municipalities had signalled the falling popularity of the then government in power and voters' turn towards radical left or extreme-right political voices. The former openly questioned Greece's ‘independence' and position within Europe whereas the latter engaged in a nationalistic rhetoric of ethnic superiority [see overview of the project - link will be inserted here]. It is not hyperbolic to argue that Greek society at the time was divided and overwhelmed by disappointment and despair. 
As pinpointed in media narrations, Amphipolis was portrayed as a source of hope [14] that could potentially reverse Greeks' psychology and relieve their stress of coping with economic difficulties (To Vima, September 28, 2014).

'What's missing in Greece is hope. It feels like endless austerity measures. In Amphipolis they [the local stakeholders] view the [Amphipolis] as the hope that could regenerate Greece ${ }^{18}$ '

Proto Thema, September 29, 2014 [14]

The slow and steady emersion of finds fed public imagination and distracted audiences from their 'gloomy reality' (Kathimerini, September 14, 2014), 'their everyday misery' (To Vima, September 14, 2014) and 'their grey daily life of the crisis' (Kathimerini, September 29, 2014). In other words, Amphipolis was portrayed by the media as a means of escapism from real-life pessimism and distress (Livingstone 1988, 66). This is graphically represented in the cartoons of the relevant newspaper articles. An indicative example is the political cartoon of Yiannis Kyriakopoulos (aka KYR) depicting a Greek family where the mother says: 'Today we have nothing to eat! Let's close our eyes and travel mentally to Amphipolis... ${ }^{19}$, (www.i-kyr.gr).

More interestingly, the Greek press described Amphipolis as a source of national uplift (Kathimerini, September 13, 2014) and a way to re-establish Greeks' integrity towards the 'others' (Ethnos, September 20, 2014). To better understand this we need to

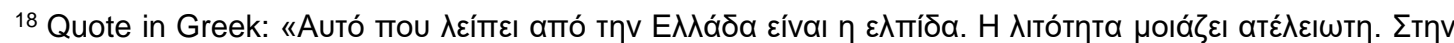

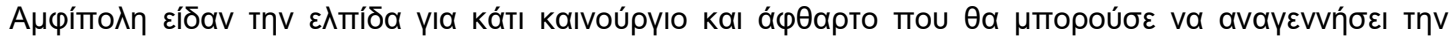

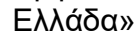

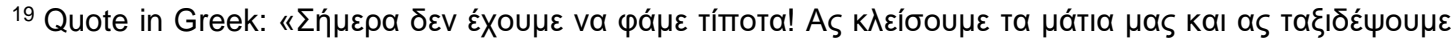

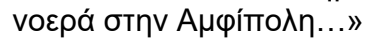


consider that once Greece became the epicentre of the European Debt crisis, several foreign media interpreted its causes through a 'cultural' rhetoric that blamed ethnic idiosyncrasy (Mylonas, 2012). In these accounts Greeks, who were stereotypically depicted as corrupt and lazy, were described as a burden on their European counterparts (Bickes, Otten and Chelsea 2014; Talalay, 2003). Such narrations created a sentiment of shame and humiliation within the country's borders.

Therefore, the Amphipolis spectacle was presented as a 'source of pride' (Avgi, September 3, 2014) emphasising the country's 'privilege' to ceaselessly produce 'incredible [archaeological] wealth' (To Vima, September 19, 2014). Amphipolis, as a find 'of international significance' that extended 'much beyond Greece's narrow borders' (Kathimerini, September 16, 2014), could not merely improve the country's global image but also avail as a 'hyper-replenishment to the crisis-wounded national identity' (Kathimerini, September 14, 2014).

Furthermore, the universal symbolism of glory represented by Alexander the Great known for bringing all the Greeks together during ancient times - could be an antidote to the stigma assigned to the Greek people. This stigma had divided public opinion between heavy self-criticism for the causes of the crisis and criticism of foreign powers' castigation for their handling of the crisis (Kouki and Liakos 2015). The former was hurting national narcissism whereas the latter was perceived as threatening state independence. Both were deepening social segregation and social pessimism. In view of this, the identification of the tomb as the burial of Alexander the Great - or at least one of his close relatives- could reinstate the glory of a lost past and inspire societal unity through romantic nationalism [15-16]. 
'[I felt] immense relief. Because they [International Monetary Fund and the European press] had ridiculed Greece so much... ${ }^{20}$,

Testimony by a Greek citizen, To Vima, September 18, 2014 [15]

'We haven't realised the contribution of Amphipolis Tomb to our everyday reality [and] the interest it raises to the public that is tortured by so many problems. [Owning] to this great discovery, we returned to the study of our history. [The] monument gives as ample evidence that Greece never dies ${ }^{21}$.' (emphasis added)

Government representative, Facebook post (August 27, 2014) [16]

\section{Inequalities in the production of cultural meaning}

The third dimension of spectacle relates to the production and advancement of epistemological knowledge by those who held the political and communication power. The lead archaeologists and governing politicians were remodelled into the most legitimate agents to co-orchestrate the spectacle along with the media. Although these

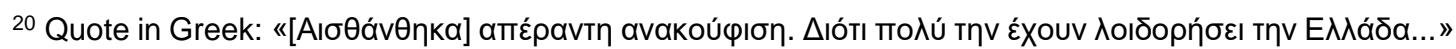

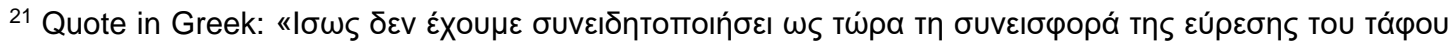

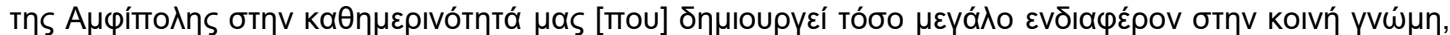

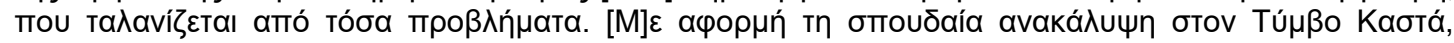

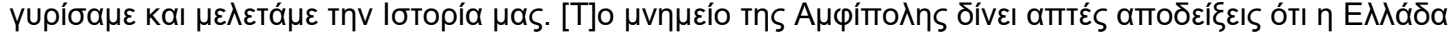

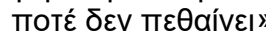


spectacle agents were most likely driven by different motives, they all shared a common desire to enter and remain in the spectacle's spotlight. In Debord's (1967) theory, inequalities between spectacle production by specific agents and consumption by general audiences create a monologue that aims to turn spectators into passive receivers. Although, we do not have the evidence to suggest that the spectators were indeed passive, we observe that the Amphipolis media arena of scientific discourse affirms this gap between 'experts' and 'non-experts'. This gap becomes apparent through both mal-informed non-expert views and spectacularised expert quarrels disorienting the public and hindering its meaningful participation in the production of cultural meaning.

First, the exercise of political power in shaping the spectacle is evident by the fact that shortly after the revelation of the tomb, a televised tour of the state leadership signalled the find's significance and drew the lines of media discourses. Standing in front of the marble Sphinxes, spectators watched the Prime Minister characterising the discovery as 'exceptionally important' and their own (Greeks') feelings of affection and pride (Proto Thema, August 12, 2014). The enthusiasm of the government leader was further paraded by the expert archaeological detail with which he described the find on camera (To Vima, August 2014). The political 'validation of significance' as marked by the PM's visit at the site and a subsequent array of state announcements were catalyst to the metamorphosis of Amphipolis into one of the most popular media topics during the studied period. Officials at the Ministry of Culture fed the Amphipolis spectacle with press releases, official announcements and public statements on a rather systematic basis. Political circles went as far as to express 'scientific' opinions [17] and circulate field photographs on social media. 
'The position that it will take archaeologists 2-3 weeks for to synthesize the archaeological data in Ancient Amphipolis and draw their final conclusions was expressed on Wednesday by the Minister of Culture who confirmed that the country is faced with a significant find.'

Ethnos, August 12, 2014 [17]

From the very beginning, there were minority voices that attempted to deal with the issue critically, not only reproductively, by exposing political and communication tactics and discussing scientific ethics. Furthermore, the phenomenal exposure of the Tomb coupled with the project's quite unorthodox pace and the publication of its preliminary and thus tentative results gave rise to conflict and debate amongst experts themselves (Kathimerini, September 11, 2014; September 14, 2014; September 28, 2014; Proto Thema, September 1, 2014; Ta Nea, September 13, 2014; To Vima, August 27, 2014; September 18, 2014; September 21, 2014). In particular, the management and communication strategy of the excavations provoked the discontent of various specialists, who accused Amphipolis' archaeologists and the government for revamping a scientific process into a 'reality show' (Ta Nea, September 3, 2014; Avgi, September 4, 2014; September 12, 2014) [21]. But despite dissenting voices, the popularisation of the archaeological science was mostly practised in gossiping terms while claiming transparent communication rhetoric (To Vima, September 18, 2014; Kathimerini, September 23, 2014).

Especially, the identification of the archaeological find triggered heated media discussions and long-lived speculation over the profile and name of the "Amphipolis 
tenant', a term coined and popularised by the press. Although official interpretation dated the site to the last quarter of the 4th century BC, advancing the theory that it belonged to a member of Alexander's family, circulating scenarios featured various 'candidates' and Alexander himself. Unfortunately, there were several archaeologists who paraded before the spectacle stage as 'fortune tellers' (Kathimerini, September 28, 2014) proposing various and often contradicting hypotheses regarding the find's chronology, intactness and identity (Avgi, September 16, 2014; Kathimerini, September 11, 2014). The media exploited such scientific debates between on-site archaeologists and other experts and often impersonated them to foster spectacularised quarrels, especially where discord moved beyond scientific boundaries. A typical example of experts' debate is reflected in passage [18] in which Archaeology Professor, Olga Palagia from the University of Athens contradicts official interpretations through an opposition newspaper and the quite ironic response of the excavations' director [19].

'The similarities with the Mausoleum of Octavian Augustus, the Roman dating of Caryatids and the great event of the battle of Philippi in the area allow us to formulate the hypothesis that this is an Octavian and Mark Antony's victory monument ${ }^{22}$,

Palagia's interview at Avgi, September 16, 2014 [18]

'The only thing all these archaeologists want is five minutes of television exposure $^{23}$,

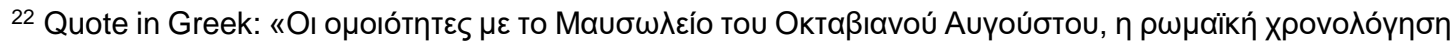

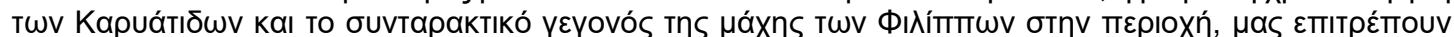

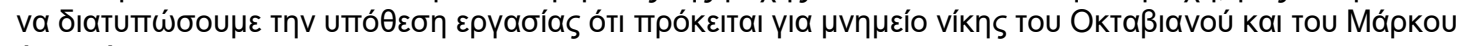
Avtwvíou».

${ }^{23}$ Quote in Greek: «O^ol autoí ol apXaı

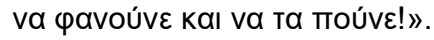




\section{Deconstructing the heritage spectacle}

The sections above outline how Amphipolis evolved into a media spectacle. By using the three diachronic dimensions of spectacle, analysed in Debord (1967) and elaborated by Kaplan (2012), we identified the underpinning mechanisms of the production of the Amphipolis spectacle. We highlighted the pivotal role of media in creating banal fantasies and in using heritage for the development of those fantasies. Despite sporadic dissenting voices, the dominant discourses of the Amphipolis spectacle, which were more attractive to audiences and easier to digest, were the ones that reinstated national identity and the public quarrels amongst experts.

As our analysis demonstrates, the spectacle of Amphipolis was closely linked to notions of salvation from those crises that the Greeks had recently experienced. The media emphasised the find's potential to compensate for national humiliation, economic hardships, political disappointment and failed diplomacy. Throughout the spectacle process, the interconnection of emotion generation with national imagination was critical (Anderson 1983). Accordingly, discourses could appease socio-political divisions by a false sense of an organic community with a common past and collective accomplishments. As Debord (1967) suggests, the spectacle aims at the collective amnesia of social relations so that sameness, disconnected from community identity, can eventually prevail (Kaplan 2012). Similarly for Amphipolis, the heritage spectacle was used by politicians as a means to disconnect the Greek public from their unsettling 
civic and societal identities and replace them with imagined ones so that viewers could see themselves as part of a glorious and homogeneous nation.

The fostering of power inequalities in forming Amphipolis narratives was clearly substantiated in the way the spectacle developed. Political agents and journalists not only encouraged experts' speculation over Amphipolis' developments but also reproduced a quasi-scientific monologue that was enriched by populist rhetoric (e.g. nationalism). Upon the unfolding of the Amphipolis spectacle, this monologue was further transformed by the media into a soap opera. It became a contested terrain of experts and other spectacle agents who disputed over the finds' interpretation and by extension, meaning to Greek society. Further, the expression of such interpretations in jargon language and scientific terminology, could only induce a sense of 'pseudointimacy' with the wider public (Debord 1967, thesis 24).

The deconstruction of the Amphipolis spectacle into its main components could be depicted into the following framework of heritage spectacle (fig. 1). We suggest that the proposed framework has the potential to act as an analytical tool for understanding and deconstructing the ways in which heritage is being spectacularized.

Our proposed framework of heritage spectacle has at its core the use of iconic, cultural symbols derived from a 'glorious', imagined and nostalgic past (WHAT component of diagram). The spectacle is mainly created and communicated by agents of power either knowledge experts or politicians along with mass media (WHO component of diagram). A key dynamic pivot of the spectacle is the aim of the 'agents of power' to disorientate the public and its relief from present reality. In the Amphipolis case this 
was endeavoured through the communication of archaeological developments at Amphipolis in nationalistic terms. It was further sought through the dramatization and spectacularisation of the past with the ultimate goal to provoke strong emotions of pride, excitement and affection (HOW dimension of diagram). For Amphipolis, the dominant narrative revolved around the role of Amphipolis in generating hopes for a reborn new Greek state through the reproduction of dramatized recitals invested with emotional appeals, both romantic and nationalistic.

In the case of Amphipolis, the spectacle narratives developed by the agents of power aimed at distracting and disorientating the public from social dystopia (WHY component of diagram). However, it is worth stressing, at this point, that the spectacle itself might not have a pre-specified goal but its impacts can be viewed a posteriori. In addition, it can have as many goals as agents.

\section{[INSERT FIGURE 1 ABOUT HERE]}

From above it becomes apparent that a heritage spectacle orchestrated by political or other agents of of power intends to to distract or disorientate societies through evoking images and images, through alienation (e.g. the expert knowledge game) or through unification (e.g. ideas of nation). Indeed, emotions-based imaginations are key dimensions of contemporary societies rendering audiences to cultural consumers (see Abercrombie and Longhurst 1998; Bagnall 1996; Campbell 1987). Moreover, Campbell (1987) suggests that it is the power of imagination that enables individuals to achieve this emotional engagement and control. Hence, spectacle seeks to stimulate 
excessive reactions and works more effectively when it touches highly sensitive strings of the human psyche (Kershaw 2003, 592). Imagery and emotions coupled with reimagination aim to provide what Boje calls a 'camouflaged society' (Boje 2001, 434).

Ex-post, the Amphipolis spectacle was proved to be partly a nationalistic movement that aimed to create a sense of shared identity, culture and ethnicity, reconstructing itself into a symbolic capital that could foster national culture. Danforth analyses how in nationalist discourses a national culture is considered to be a territorially based and mutually exclusive entity characterized by homogeneity, boundedness and continuity (2010, 578). This national culture is then disseminated by the state to its citizens through various institutions, such as the mass media (Danforth 2010, 578). As Danforth rightly argues, nationalist myths of shared descent from common ancestors with their imagery of kinship, blood ties and racial continuity constitute one of the most powerful tools with which to 'imagine' a national community (Danforth 2010, 578). This tool can become even more powerful when the ancestors involved are linked to ancient Macedonians and Alexander the Great, in particular, whose perception in Greek imagination is both powerful and contested by its Balkan neighbours. Therefore, the claim of a direct connection between Amphipolis and Alexander the Great touched on a sensitive spot of the Greek nationalist psyche while facilitating the notion of reestablishing a sovereign state and reversing its distortion during the crisis.

\section{Conclusion}

In this article we attempted to address an under-explored issue in the field of heritage studies - that of the use of heritage in spectacle creation during socio-economic crises. 
By employing the example of Amphipolis excavations in Greece, this article offers the first in-depth analysis of the ways in which heritage is being spectacularised. Our analysis was facilitated and filtered through the lenses of critical theory and in particular the work of Guy Debord on spectacle creation (1967). Kaplan's additional interpretation of Debord's theory of spectacle (2012) proved to be pertinent for our analysis. Following the three diachronic dimensions of spectacle, as articulated in Kaplan (2012), we conclude that banal fantasies, representations of a unified society and power inequalities between spectacle agents and receivers played instrumental roles in setting the scene of the dominant discourses in the case of Amphipolis excavations. The repetitive reproduction and symbolisation of archaeological finds (e.g. Sphinxes, Caryatids), the celebration of archaeologists as heroes and the cultivation of redemption and hopes related to the future development and territorial sovereignty of the country were expressed through romantic and nationalist language. These discourses intended to stimulate a public sentiment of 'owe', offer an escape from socio-economic dystopia and foster a re-imagined nation that had recently lost its glory and pride. Further, the high media exposure of experts' quarrels added to the Amphipolis 'drama' whereas the usurpation of expert views by non-experts increased power imbalances in the communication of scientific knowledge (i.e. politicization of archaeological science).

Ultimately, this article proposed a provisional analytical framework for heritage spectacles. Using the case study of the Amphipolis excavations, we deconstructed the mechanics of heritage spectacularisation by exploring what was utilized, by whom, why and in what ways during the spectacularisation process of heritage in the context of the Greek economic crisis. We argued that banal symbols were largely utilized by powerful 
holders of knowledge, governance and communication leading to the disorientatation of the wider public from critical contemporary issues. We contend that our proposed framework can provide a starting tool for analysing similar forms of heritage spectacles in different contexts. More research on heritage spectacles will refine this tool. Its testing through the application of other spectacle phenomena is necessary so that it can offer an analytical tool for deconstructing the processes by which heritage is being spectacularized in other cultural and socio-political contexts.

Overall, we hope that with this article we instigated a new theoretical avenue of exploration in heritage studies - that of heritage spectacle. An additional area for further research, in the context of Amphipolis, is the investigation of the reception of Amphipolis spectacle by the public. Although Debord and many of his consequent followers have assumed a passive audience, it would be wrong to presuppose that receivers remain entirely passive towards the unfolding of the spectacle. As Gotham (2007) suggests, although spectacles may intend to distract individuals from current social problems, opposing movements can offer competing interpretations (Gotham 2007, 86). This implies that a full interpretation of a heritage spectacle would treat it as an active two-way process of social construction and negotiation that in turn produces various de-codings (Gotham 2007).

We would like to conclude this article with a few critical questions emerging from the case of Amphipolis regarding the role of archaeologists' position and responsibility to communicate scientific research and the role of heritage, especially in times of socioeconomic hardships. How ethical is the popularisation of heritage and archaeology by mass media when this conforms to political agendas and when it is used to provoke 
emotions that intend to disorientate the public from major social and political issues? In the case of Amphipolis, the communication of archaeological knowledge with the public was used as an argument to legitimise the media exposure of the excavations. Nonetheless, the extensive use of archaeological jargon, the wide circulation of unconfirmed hypotheses and the public quarrels between experts ended up empowering political allegations. In fact, daily and mass exposure created a noise domain that could easily be manipulated either in accordance or in contrast to the intentions of spectacle agents .

This phenomental media exposure of Amphipolis that took the form of a soap opera in which, eventually, many archaeologists took part, raises critical questions about the role of archaeologists in situations of crisis. We would thus like to conclude this article by advocating for the obligation of archaeologists, and heritage professionals more generally, to resist and fight (rather than facilitate and support) against political endeavours to 'abuse' heritage with the goal disorientate the public from critical, contemporary socio-economic issues.

\section{References}

1. Abercrombie, Nicholas, and Brian J. Longhurst. 1998. Audiences: A sociological theory of performance and imagination. London: Sage.

2. Adorno, Theodor W, and Max Horkheimer. 1997. Dialectic of enlightenment. London: Verso

3. Anderson, Benedict. 1983. Imagined communities. London: Verso.

4. Andrews, David L. 2006. "Disneyization, Debord, and the integrated NBA spectacle.” Social Semiotics 16(1), 89-102. 
5. Apter, David E., and James Joll, eds. 1971. Anarchism today. Springer.

6. Archibald, Zosia, Catherine Morgan, David M. Smith, Helen Murphy-Smith, Robert Pitt, Chryssanthi Papadopoulou, Fabienne Marchand, Matthew Haysom, Alexandra Livarda, and Daniel Stewart. "ARCHAEOLOGY IN GREECE 2013-2014." Archaeological Reports, no. 60 (2013): 1-135. http://www.jstor.org/stable/43187051.

7. Bagnall. Gaynor. 1996. "Consuming the Past." In Consumption Matters, edited by Edgell, Stephen, Kevin Hetherington, and Alan Warde, 227-247. Oxford: Blackwell.

8. Berman, Russell, David Pan, and Paul Piccone. 1990. "The society of the spectacle 20 years later: A discussion.” Telos 1990.86, 81-102.

9. Beeman, William. O. 1993. "The Anthropology of Theater and Spectacle". Annual Review of Anthropology, 22, 369-393. www.jstor.org/stable/2155853

10. Bickes, Hans, Tina, Otten, and Laura Chelsea, Weymann. 2014. "The Financial Crisis in the German and English press: Metaphorical Structures in the Media Coverage on Greece, Spain and Italy”. Discourse \& Society, 25(4): 424-445. doi: $10.1177 / 0957926514536956$

11. Billig, Michael. 1995. Banal Nationalism. London: Sage.

12. Boje, David. M. 2001. "Carnivalesque resistance to global spectacle: A critical postmodern theory of public administration". Administrative Theory \& Praxis, 23(3): 431-458. doi: 10.1080/10841806.2001.11643535

13. Boje, David M., Grace Ann Rosile, Rita A. Durant, and John T. Luhman. 2004. "Enron spectacles: A critical dramaturgical analysis." Organization Studies 25 (5), 751-774.

14. Brown, Douglas A. 1996. "Revisiting the Discourses of Art, Beauty and Sport from the 1906 Consultative Conference for the Arts, Literature and Sport”. OLYMPIKA-LONDON ONTARIO- 5: 1-24. 
15. Campbell, Colin. 1987. The Romantic Ethic and the Spirit of Modern Consumerism. Oxford: Basil Blackwell.

16. Colley, Sarah. 2005. “ 'Consumer choice’and public archaeology in and beyond the academy". Australian Archaeology, 61(1), 56-63. doi:10.1080/03122417.2005.11681821

17. Corbin, Juliet M., and Anselm Strauss. 1990. "Grounded theory research: Procedures, canons, and evaluative criteria." Qualitative sociology 13 (1), 3-21.

18. Creak, Simon. 2010. "Sport and the Theatrics of Power in a Postcolonial State: The National Games of 1960s Laos”. Asian Studies Review, 34(2), 191-210. doi: $10.1080 / 10357821003802011$

19. Damaskos, Dimitris, and Dimitris Plantzos, eds. 2008. A Singular Antiquity: Archaeology and Hellenic Identity in twentieth-century Greece. Athens: Benaki Museum.

20. Danforth, Loring, M., 2010. “Ancient Macedonia, Alexander the Great and the Star or Sun of Vergina: National symbols and the conflict between Greece and the Republic of Macedonia”. In A Companion to Ancient Macedonia, edited by Joseph Roisman and Ian Worthington, 572-598. Wiley-Blackwell.

21. Debord, Guy. 1983[1967]. The Society of the Spectacle. Detroit, MI: Black and Red Press.

22. Edelman, Murray. 1988. Constructing the Political Spectacle. Chicago: Chicago University Press.

23. Gombin, Richard. 1970. "The ideology and practice of contestation seen through recent events in France." Government and Opposition 5(4), 410-429.

24. Gotham, Kevin Fox. 2007. “Critical theory and Katrina”. City, 11(1), 81-99. doi: $10.1080 / 13604810701200870$ 
25. Kotsakis, Kostas. 1998. "The Past is Ours: Images of Greek Macedonia”. In Archaeology Under Fire: Nationalism, Politics, Heritage in the Eastern Mediterranean and the Middle East, edited by Lynn Meskell, 44-67. London: Routledge.

26. Harvey, David. 1990. "Between space and time: reflections on the geographical imagination1." Annals of the Association of American Geographers 80 (3), 418434.

27. Hamilakis, Yannis. 2007. The Nation and its Ruins: Antiquity, Archaeology, and National Imagination in Greece. Oxford: Oxford University Press.

28. Hamilakis, Yannis. 2015. "Archaeo-Politics in Macedonia". Accessed 10 October 2016.

http://www.lrb.co.uk/blog/2015/01/22/yannis-hamilakis/archaeo-politics-inmacedonia/

29. Hamilakis, Yannis, and Eleana Yalouri. 1996. “Antiquities as Symbolic Capital in Modern Greek Society”, Antiquity, 70(267): 117-129. • • DOI: https://doi.org/10.1017/S0003598X00082934

30. Harmanşah, Ömür. 2015. "ISIS, Heritage, and the Spectacles of Destruction in the Global Media". Near Eastern Archaeology, 78(3): 170-177. doi: 10.5615/neareastarch.78.3.0170

31. Harp, Dustin, Jaime Loke and Ingrid Bachmann. 2016. "The Spectacle of Politics: Wendy Davis, Abortion, and Pink Shoes in the Texas 'fillybuster'". Journal of Gender Studies, 1-13.

doi:10.1080/09589236.2016.1175924 
32. Jackson, Steven J, and Jay Scherer. 2013. "Rugby World Cup 2011: Sport mega-events and the Contested Terrain of Space, Bodies and Commodities". Sport in Society, 16(7): 883-898.

http://dx.doi.org/10.1080/17430437.2013.791156

33. Kang, Jaeho, and Jilly Traganou. 2011. "The Beijing national stadium as mediaspace.” Design and Culture 3(2), 145-163.

34. Kaplan, Richard L. 2012. "Between Mass Society and Revolutionary Praxis: The Contradictions of Guy Debord's Society of the Spectacle". European Journal of Cultural Studies, 15(4): 457-478.

doi: $10.1177 / 1367549412442208$

35. Kellner, Douglas. 1983. "Critical theory, commodities and the consumer society." Theory, Culture \& Society 1(3): 66-83.

36. Kellner, Douglas. 2003. Media Spectacle. London: Routledge.

37. Kellner, Douglas. 2010. "Media spectacle and media events: Some critical reflections." Media events in a global age, 76-91.

38. Kellner, Douglas. 2015. Media spectacle and the Crisis of Democracy: Terrorism, War, and Election Battles. London: Routledge.

39. Kershaw, Baz. 2001. "Dramas of the performative society: Theatre at the end of its tether." New Theatre Quarterly 17(3), 203-211.

40. Kershaw, Baz. 2003. "Curiosity or Contempt: On Spectacle, the Human, and Activism”. Theatre Journal, 55(4): 591-611. doi: 10.1353/tj.2003.0170

41. Kong, Lily and Brenda SA Yeoh. 1997. "The construction of National Identity through the Production of Ritual and Spectacle: an Analysis of National Day Parades in Singapore". Political geography, 16(3): 213-239. http://dx.doi.org/10.1016/0962-6298(95)00135-2 
42. Kouki, Hara and Antonis Liakos. 2015. "Narrating the Story of a failed National Transition: Discourses on the Greek Crisis, 2010-2014. Historein, 15(1): 4961. doi: http://dx.doi.org/10.12681/historein.318

43. Livingstone, Sonia M. 1988. "Why People watch Soap Opera: An Analysis of the Explanations of British Viewers". European Journal of communication, 3(1): 55-80.

44. MacAloon, John. 2006. "The theory of spectacle: Reviewing Olympic ethnography”. In National Identity and Global Sports Events, edited by Alan Tomlinson and Christopher Young, 15-40. New York: State University of New York Press.

45. Markantonatou, Maria. 2013. "Diagnosis, Treatment, and Effects of the Crisis in Greece: A" Special Case" or a" Test Case"?”. MPIfG Discussion Paper 13/3, Cologne: Max Planck Institute for the Study of Societies.

46. Matsaganis, Manos. 2013. "The Greek crisis: social impact and policy responses". Berlin: Department of Western Europe/North America, Berlin. Accessed 05 September 2016. http://library.fes.de/pdf-files/id/10314.pdf

47. Maurer, Kathrin. 2009. “Archeology as Spectacle: Heinrich Schliemann's Media of Excavation". German Studies Review, 32(2): 303-317. http://www.jstor.org/stable/40574802

48. Mavromatidis, Fotis. 2010. "The Role of the European Union in the Name Dispute between Greece and FYR Macedonia”. Journal of Contemporary European Studies, 18(1): 47-62.

doi: $10.1080 / 14782801003638703$

49. Mylonas, Yiannis. 2012. "Media and the Economic Crisis of the EU: The 'Culturalization'of a systemic crisis and Bild-Zeitung's Framing of Greece”. 
Open Access Journal for a Global Sustainable Information Society, 10(2): 646671.

50. Overton, James. 1980. "Promoting "The Real Newfoundland" Culture as Tourist Commodity.” Studies in Political Economy 4.1 (1980): 115-137.

51. Parry, Simon. 2010. "Imagining cosmopolitan space: spectacle, rice and global citizenship." Research in Drama Education: The Journal of Applied Theatre and Performance 15(3), 317-337.

52. Peponis, John. 1989. "Space, culture and urban design in late modernism and after." Ekistics, 93-108.

53. Plantzos, Dimitrios. 2012. "The Glory That Was Not: Embodying the Classical in Contemporary Greece”. Interactions: Studies in Communication \& Culture, 3(2): 147-171. https://doi.org/10.1386/iscc.3.2.147_1

54. Plantzos, Dimitrios. 2014. Amphipolitics. The Athens Review of Books. Available [in Greek]. Accessed 01 September 2016. http://athensreviewofbooks.com/?p=1333

55. Rosati, Clayton. 2012. 'Guy Debord, 'gilded poverty', and the contemporary crisis: On Marxism, spectacle, and the banality of inequality." Culture, Theory and Critique 53(3): 339-363.

56. Roberts, David. 2003. “Towards a Genealogy and Typology of Spectacle Some Comments on Debord." Thesis Eleven 75(1), 54-68.

57. Ross, Christine. 1977. "The projective shift between installation art and new media art: from distantiation to connectivity." American Art 1964 (1977): 20001. 
58. Shields, Rob. 1989. "Social spatialization and the built environment: the West Edmonton Mall." Environment and Planning D: Society and Space 7(2), 147164.

59. Schirato, Tony and Jennifer Webb. 2004. "The Media as Spectacle: September 11 as Soap Opera”. Journal for Cultural Research, 8(4): 411-423.

60. Silverstone, Roger. 1994. Television and Everyday Life. London: Routledge.

61. Smith, Laurajane. 2006. Uses of Heritage. London: Routledge.

62. Talalay, Lauren E. 2013. "Drawing Conclusions: Greek Antiquity, The€ conomic Crisis, and Political Cartoons". Journal of Modern Greek Studies, 31(2): 249-276. doi: 10.1353/mgs.2013.0023

63. Thomas, Sophie. 2012. "Displaying Egypt: Archaeology, Spectacle, and the Museum in the Early Nineteenth Century". Journal of Literature and Science, 5(1): 6-22.

64. Tomlinson, Alan. 2002. "Theorising spectacle: beyond Debord." Power games: A critical sociology of sport, 44-60.

65. Tomlinson, Alan and Christopher Young. 2006. "Culture, Politics and Spectacle in the Global Sports Event - an Introduction". In National Identity and Global Sports Events, edited by Alan Tomlinson and Christopher Young, 1-14. Albany: State University of New York Press.

66. Vournelis, Leonidas., 2016. “Alexander's Great Treasure: Wonder and Mistrust in Neoliberal Greece". History and Anthropology, 27(1):121-133.

67. Williams, Stephan B., Oscar Pizarro, and Brendan Foley. 2016. "Return to Antikythera: Multi-Session SLAM based AUV mapping of a first century BC wreck site". Field and Service Robotics, 113: 45-59.

68. Yalouri, Eleana. 2001. The Acropolis: Global Fame, Local Claim. Oxford: Berg 


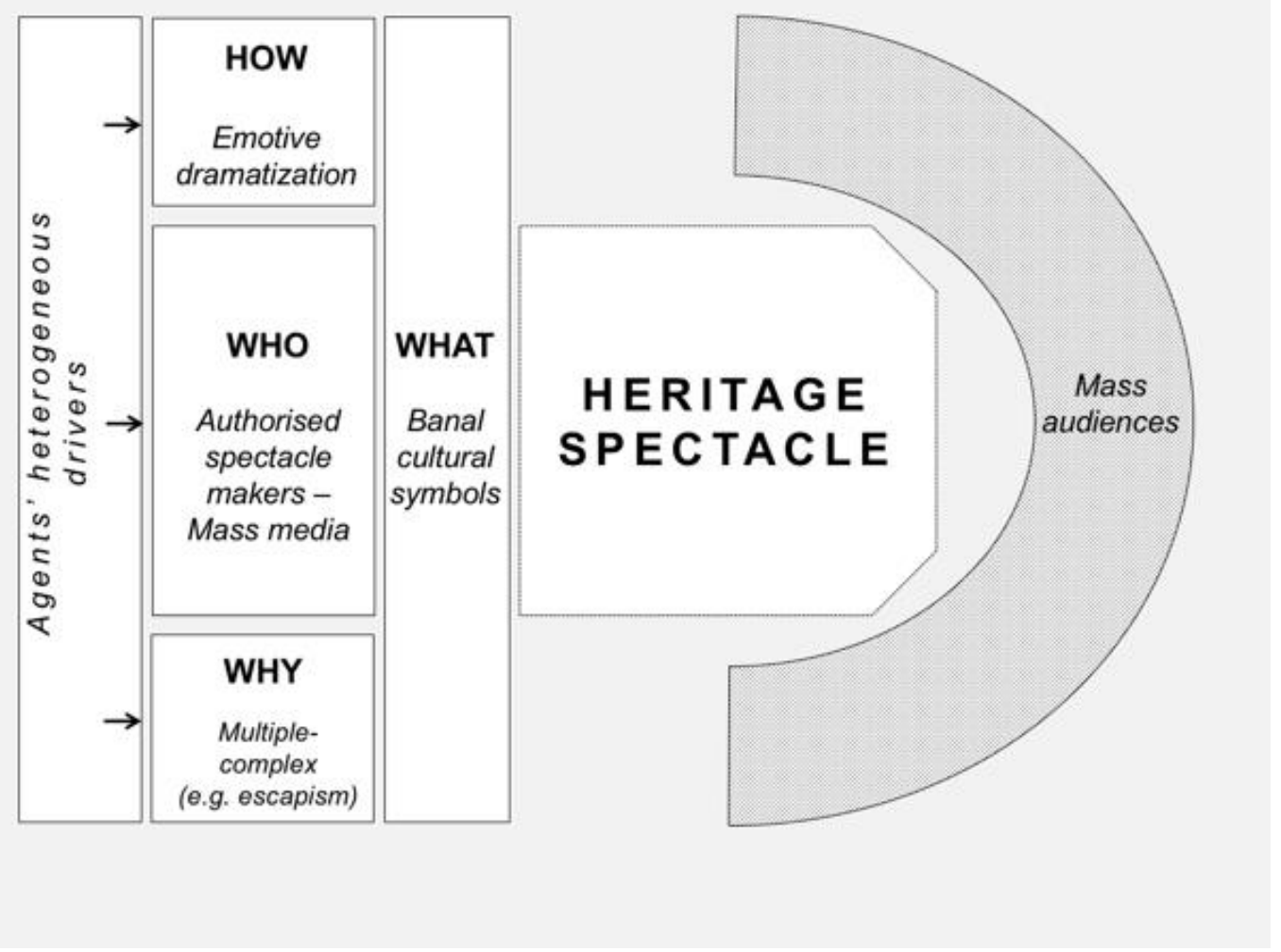

Figure 1. A theoretical framework for analysing heritage spectacles in schematic form. 